\title{
Editorial: Simplification and regulation
}

Governments around the world have in recent years become increasingly aware that because of changing demographies, the role of the state is bound to diminish in pension provision. The reason is simply that there will be too few workers to support too many pensioners.

One answer being widely adopted in the increased involvement of employers is the provision of pensions. Stakeholder in the UK is just one instance of the attempt to encourage wider employer-based pension arrangements. But there are problems, the main one being that employers are increasingly reluctant to do so - or only to provide what will in the event be inadequate retirement schemes, mostly defined contribution.

Why are they so reluctant? One reason, of course, is cost - although it was not the avoidance of cost which saw the flourishing of defined benefit schemes in the 1950s and later. The major concern then was the need to attract and retain staff - and despite the present turndown, that is still a major factor. Another element is fashion, and here the attraction of defined contribution schemes has manifested itself to the workforce, although maybe only provisionally. And a major factor in decision-making by employers is the perception that defined benefit schemes are inappropriate for a mobile workforce. Meanwhile the main disincentive to pension provision remains the excessive number of rules.
The rules have led to much increased cost and unpredictability. In the UK the introduction of the immensely foolish FRS 17 under which deficits and surpluses arising in defined benefit schemes have to be reflected in balance sheets, is leading to excessive volatility in employer's accounts. This causes grief to the individual investor - and the figures then have to be stripped down by the institutional investor. What a waste of effort - and what a disincentive to provide defined benefit arrangements with no benefit to the concerned shareholder.

Another has been the misguided introduction of the minimum funding requirement, now in the course of being abolished. And not least, included among all this, is the introduction of substantial swathes of regulation.

The introduction of the regulations are understandable. First there was the Maxwell Affair, under which several thousand pensioners in the Mirror Group and elsewhere were at danger of losing their pension entitlements. The fact that the failure was partly assisted by the introduction of the regulation of investment managers (where the alleged fraud took place, rather than in the pension scheme) has of course hardly been touched upon. And later, although not much later, was the personal pensions mis-selling farrago, itself largely prompted by over-enthusiastic promotion of government policy to dismantle occupational pension schemes in favour 
of personal pensions. The UK

government has suddenly become aware that the balance between protection of the consumer and the employer's involvement in pension provision has now become unbalanced. Employers are now faced with a massive increase in pensions paperwork, an exposure to substantial fines for minor

maladministration, a pensions ombudsman on a mission to enforce, and a regulator without a sense of irony. The recent announcement by Opra, for example, that it was publishing its determinations against employers 'in the spirit of the Freedom of Information Act' not only possibly itself infringes the spirit of the Human Rights Act and the right to privacy, but directly counteracts the spirit of the Freedom of Information Act which encourages disclosure of the operations of the public bodies; in other words, what the Act seeks is publication of the minutes of the Authority, not of the misfeasance of employers.

But now there is a regulatory spring in the air. First, it has been announced that the Inland Revenue is reviewing from basic principles the taxation rules applying to pension schemes. The Augean stables of fiscal regulation with around 1,500 pages of rules with innumerable different regimes, separate tax reliefs, the proliferation of UURBS, FURBs, AVCs, stakeholder and other arrangements is not only incomprehensible to the public but also costly to administer for both the Revenue and the employer - are now to be cleansed. The fiscal rules are one among many minor irritants for employers and pension scheme managers - and the vast majority of the restrictions are those that either save the Treasury money or are perceived to do so. In fact, as the figures indicate the majority of individuals cannot afford even the reliefs currently available, so the need to ensure that they are not breached seems unnecessary. The position is well understood by the Inland Revenue (and No 10, though not the Treasury) and the fact that the abolition of most of the restrictions (including the politically correct but pointless earnings cap) would cost little or nothing for the Treasury is also understood. Whether in the end there will indeed be reform is uncertain - the political inertia is very strong — but at least the powers that be have perceived that all is not well in the fiscal regulatory field, and are thinking, if not doing anything, about it.

Meanwhile, on another front, a former Chairman (Alan Pickering) of the National Association of Pension Funds in the UK has been appointed to lead an inquiry into over-regulation on the consumer side. It was only to be expected that after Maxwell, the call would be 'never again'. And indeed what happened was unattractive. But maintaining the balance between protection of the consumer, and making life so difficult for the producer that he produces nothing at all, is an uneasy one. The evidence is clear that the current situation is inappropriate. The main question that the Pickering Inquiry will have to examine is whether the cost-benefit analysis of regulation works - and if not, what is a better one?

It is a mantra that consumers need to feel secure in their pension arrangements, otherwise they will not bother to make contributions to them, and there is some truth to that. At the same time, if the costs of regulation are so high that either employers refuse to provide pensions (at present they are not compulsory) the result will be (as the Americans so pithily explained about their Vietnam policy) that they destroyed the village to save it.

The law on pension schemes is, of course, notoriously complex, and there are several reasons why this is so. 
Sometimes it is because there is a conflict of objectives, or the objectives are not quite clear. Sometimes it is because one idea is built on top of another idea. Sometimes it is poor draftsmanship. Sometimes it is because the draftsman does not trust those for whom he is legislating.

Whatever the reason, there is no doubt that the present legislative position is unacceptable; fortunately reform is in the air. In pensions fiscal legislation, the Tax Law Rewrite project with a $\mathcal{L}^{25 \mathrm{~m}}$ budget is slowly and painfully rewriting the existing tax law in English.

Moreover, the NAPF discussion document issued some years ago on tax simplification in pensions is being seriously examined by groups in the Treasury and the Inland Revenue looking at tax simplification.

Consumer protection legislation in pensions has a shorter history. There has been ad hoc legislation since the mid-1980s; much of it was consolidated into the Pension Schemes Act 1993 and could have been manageable if it had not been for the Pensions Act 1995. Even that might have been satisfactory if it had not been for the flood of statutory instruments that followed. None of this is manageable in practice without access to an electronic information system these days.

Alan Pickering's efforts are due to be published sometime in mid-2002. They will not immediately solve all the problems of over-regulation (such as FRS 17), but they will address most of them. Before his team gets down to cutting back the thicket of regulation it will face, however, the same problem that currently faces the Myners reforms on MFR everyone knew that MFR was wrong (it only having been introduced and even then in a much truncated form after the Goode report in 1993) but not everyone agrees on what should replace it, and it is not ten years old.
Any reform needs to examine some basic principles underlying the design of legislation. In practice many of these basic principles do not survive the complexities of the UK legislative process so even with the best of intentions the consequences may be the opposite of that intended.

The first objective is to settle the purpose of the legislation. Fiscal pensions legislation, for example, has a dual objective: the granting of fiscal neutrality, while protecting the interests of the Treasury, to encourage the provision of protection against the risk of living beyond working age. Social legislation has a similar but different objective: the protection of the public (the consumer) while encouraging the provision of protection against the risk of living beyond working age.

If it is agreed that there should be protection (and there is an inevitable consensus that there should) there arise two questions. First, what is the right balance between protection and freedom? If protection of the consumer is not good enough, too many people will suffer (or as in Maxwell, will be perceived to suffer even if they do not actually lose out). If protection is too good, people will also suffer since the costs will be too high and fewer people will have adequate pensions provided by their employers. The key is getting the balance right. The Goode Committee understandably provided excess protection. However, trying now to redress the balance may be politically impracticable, given some of the strident voices seeking even stronger protection.

Second is the question of the way the rules are expressed. There may be a consensus that, for example, it would be sensible to have member-nominated trustees. But there is much less consensus that the rules should be over 30 pages long and complex beyond the 
understanding of the common man (or even the technical man), made even more complicated by tinkering by $\mathrm{Mr}$ (now Lord) Rooker. The draftsman needs to trust the industry to implement the policy properly and resist the inevitable calls from the anoraks of the legal profession for detailed rules.

Any reform may wish to take account of the six principles adopted by the Goode Committee itself (which were ignored both by itself and by the legislator) and which might be restated, in ten principles this time, as follows:

- The need for statements of principle: There is clearly a need to legislate by principle (rather than by detail) and include the statement of principle in the legislation (as for example in Rule One of the Civil Procedure Rules).

- The need for simplicity: Where there is a choice between simplicity and prescription, there must be a need to adopt simplicity despite the risk that there will be small but occasional and manageable abuses.

- The need for proportionality: There is clearly a need to adopt the principle of proportionality; the present excessively penal and draconian legislation merely brings the system into disrepute (it is for example counter-productive for the regulator to have the ability to impose a fine of $£ 5,000$ a head on trustees for failure to include the time of the start of the meeting in trustees' minutes).

- The need for balance: Excessive consumer protection can also be counter-productive. While consumers need to be protected by the law, especially where they cannot protect themselves, there is no requirement to immunise them completely from risk. It is necessary to accept that errors and mistakes will happen and accept that the law should not and cannot prevent every mistake. It may be that there is no longer any need for the anti-franking or the preservation laws, at least in their present form.

- The need for restraint: The law of unintended consequences applies most noticeably in pensions; even members of the judiciary are aware that imposing excessive liability, for example, on trustees (for example by outlawing exclusion clauses) merely imposes excessive costs on pension funds and employers, as Lightman J has several times observed.

- The need for flexibility: Even the finest draftsman cannot always foretell the changes in the industry or the world. The rules need to cope with change without the need to change the rules, and since the parliamentary process is so sclerotic it is difficult to reform the regulations, there needs to be a simple process for continual reform.

- The need for the acceptance of risk: There is a necessity by the regulators that they are not able to prevent all failure. They need to accept that things will go wrong - and that, within limits, the principle of moral hazard (despite pressures from public opinion) requires that collateral damage is acceptable and even necessary. The principle of minimum funding for example should go completely and be replaced by a risk warning to members; it could even be coupled with a comparative risk analysis of defined contribution schemes.

- The need for realism: Legislators need to accept that law rarely changes behaviour and usually should not try. The war against drug use is one notorious example; and even the law against murder cannot prevent the occasional death. There is no justification for anarchy; the law is needed to set the parameters, and a 
police force is needed to encourage compliance. But it is possible to have too much law as well as too little.

- The need for trust: The industry is not single-mindedly dedicated to ripping off the consumer. It is imperfect, and should always do better. But most pension schemes most of the time are managed in the best interests of the members; paradoxically most of the 'failures' in administration emerge from smaller schemes where the membership is closer to the management, and where actually regulation should be lower, not higher.

- The need for basic understanding: Pensions are not 'savings', neither are they 'pay', 'fiscally privileged', or 'a substitute for healthcare'. They are a protection against the major risk that most people face, the risk of living too long, a risk which is increasing all the time at present. That basic principle should not be undermined by short-term fixes, such as the abolition of the annuity requirement.

While the Goode Report in 1993 explored many of these issues, it avoided proper consideration of some (including the nature of surpluses) and ignored others (such as its own principle of simplicity). The Report had to respond to the knee-jerk political need to be seen to do something after Maxwell and it lacked the courage to point out that actually the failure in Maxwell arose in the statutorily supervised part of the sector (the asset management part, controlled by the now Financial Services Authority) and not in the non-statutorily supervised part, the pension fund.

These are now post-Maxwell times. It is possible to reflect carefully on what is needed and why. Moreover, it is possible to accept that systems must admit failure from time to time. There will no doubt be pressures from those who wish no loophole to be left unblocked, or who have agendas of their own. But the trend is promising; the Myners report, for example, was one of the first to have the strength of character to recommend (mostly) that there should be less law rather than more. The seeds of the Pickering Report are likely to be sown in a promising soil and climate and we should wish it well.

Meanwhile there is a deep need to reconsider not only the detail of the legislation, but also the need for the kind of regulation that is in place. There was a curious item in The Independent on 2nd November, 2001, which reported that Opra had called for, on the tenth anniversary of the Maxwell Affair, more resources. It currently spends around f $11 \mathrm{~m}$ dealing with 50,000 inquiries a year and was reported as saying that unless it has additional resources it might take another scandal of Maxwell proportions before Parliament granted the resources it needs.

The report is almost certainly inaccurate. Opra, which is a well-run and proportionate regulator, is well aware that however many resources it was allocated, it could never prevent a Maxwell-type affair being repeated, since such a prevention is impossible to guarantee. Regulation, of course, can reduce the likelihood of pensions scheme failure, but a major concern for legislators is trying to achieve a cost-benefit analysis of regulation. For example, could the $\mathcal{N}_{11 \mathrm{~m}}$ currently being spent, or at least a part of it, be better spent less in collecting information about late payments, which has rarely led to substantial losses by members, and more in paying for an improved compensation fund?

The issue of 'regulatory creep', manifested most obviously in the large Financial Services Authority tower in 
Docklands, continuing saga of the Equitable Life story, is one which will become an increasing issue over the next year or two. Meanwhile, the law courts are showing that there may be other methods of solving maladministration than slinging a mountain of paper at it.

In Allan $v$ Nolan (Leeds District Registry 12th March, 2001 [2001] 60 PBLR) Mr Allan joined a small self-administered pension scheme, although he was not employed by a sponsoring employer and knew it was in breach of Inland Revenue rules. The Inland Revenue approved trustee (the pensioneer trustee) did not know of the procedure. He arranged for the transfer of assets to it from his former pension schemes. The funds were used to purchase property; meanwhile, he improperly drew benefits from the scheme, again contrary to Inland Revenue rules.

$\mathrm{Mr}$ Allan later attempted to recover the value of the assets by way of a transfer out; he was unsuccessful, and sued two remaining trustees, who were probably insolvent, and the pensioner trustee on the grounds that he was never employed by the sponsoring employer and ought never to have been a member of the scheme and that there was a resulting trust in favour of the original scheme. The two trustees did not take part in the proceedings; the pensioner trustee disputed there had been any resulting trust or that it participated in a breach of trust; and pleaded as a defence estoppel, acquiescence and concurrence in breach of trust.

It was held in the case that where a scheme member arranges for a transfer to a scheme where he knows he is ineligible for membership, the trusts do not fail and there is no resulting trust (para 136). And where there is a resulting trust, any exemption clause in the primary trust does not apply (para
171). In the event, the claim against the pensioneer trustee was dismissed and the claim against the two trustees was dismissed in relation to the claim for a resulting trust. It was upheld insofar as it related to making investments without the plaintiff's consent.

It is a wonderful tale of rascals falling out; one day it would make a short story by Damon Runyon. Clearly the judge was not amused, nor was he disposed to grant assistance to a member who had contributed (albeit while in some financial distress) to his own downfall. He who comes to equity must come with clean hands.

At the same time the remark, thankfully not binding, that exclusion clauses in scheme deeds do not apply to resulting trusts opens a small, though no doubt eventually enlarged, hole through which claimants can crawl. It is also understandable why the Inland Revenue is trying to ensure that pensioner trustees who are operated by the Revenue as watchdogs, sign all the cheques.

There are, however, a number of regulatory issues which have emerged from this extraordinary tale; the complaint to Opra is one which is commonly made by aggrieved participants in small self-administered schemes. There should be a moratorium on such complaints since they are predominantly used to pursue business and other objectives by using improperly the existence of the regulator. The costs incurred by independent trustees is an area which needs further inquiry. Finally, however, legal aid was seen to be a fit backing for such a case must also cause some unease.

Meanwhile, in another intriguing exploit, in Balfron Trustees $v$ Peterson (9th July, 2001, [2001] 52 PBLR) a Mr Baxendale-Walker advised trustees of a pension scheme that $f 2 \mathrm{~m}$ could be extracted and paid offshore; he was later 
charged by the Serious Fraud Office.

The scheme as a consequence was in deficit and unable to discharge pension liabilities in full.

Independent solicitors had been retained to prepare the paperwork for the extraction of the assets of the scheme; the new trustee of the scheme issued proceedings against $\mathrm{Mr}$ Baxendale-Walker and others, including the solicitors. The solicitors applied to the court to have the claim dismissed on the grounds that the case against them was so weak that it should be struck out.

It was held that solicitors who advise in a case of reconstruction of a trust knowing of advice from counsel that such a reconstruction would be a breach of trust are liable to be sued for participation in the misappropriation of assets. In the event, the application by the solicitors to have the claim against them struck out was dismissed.

This is a wonderful story (not so wonderful for the distraught members, however) about a scam on a pension scheme which could form the plot for an airport novel. It is also a caution for lawyers presented with attempts to strip a scheme, even where there is apparent authority to do it. What is unusual about this story is the presence of a counsel's opinion condemning the method intended to be adopted, which should have put the advisers on warning.

Making the lawyers (and for that matter any actuaries or accountants involved) contingently liable for the scam is perhaps taking the extension of breach of trust a little too far. There could be criminal liability for conspiracy to defraud, but conspiracy to commit a breach of trust has hitherto been unknown to civil proceedings. It offers fresh opportunities to aggrieved scheme members and perhaps some added protection, but in practice for lawyers to refuse to act where they are uncomfortable with a particular scheme but merely prepare the papers may be a step too far, especially where they are not being paid a success fee.

This whole tale leaves a nasty taste in the mouth, not only in relation to the distasteful plotting, but also for the attempt to nail the insurers of the advisers. There must be a better way, and since this is a case where the Pensions

Compensation Fund should quite properly be invoked, that should have been the proper route. It may be that the decision will go to appeal, and if so this point will no doubt be properly made there.

There is no doubt that we are seeing a radical review of regulation and compliance in pensions. In both the stories of rogues and vagabonds involved in pensions affairs and in the attempts to simplify the regulations, common themes emerge; first, the existing system is excessively complex and burdensome and often counter-productive. Secondly, the existing protection agencies, the police and the civil courts, are making better progress than the more recently established regulators. As Alan Pickering continues his research into simplification of the consumer protection system in pensions, one of the big questions we need to ask ourselves, perhaps in a constructive debate with the regulators themselves, is just what can regulators really do in practice, what can we truly expect of regulators, and what kind of regulators do we need? We live in interesting times; the chances are that the future will bring simpler and better times, at least in the regulation of the pensions movement.

Robin Ellison Editor 